\title{
Diversity of Cephalopod from Selected Division of Sarawak, Malaysia
}

\author{
Zulshafiq Mohd Rubaie, Mohd Hanafi Idris, Abu Hena Mustafa Kamal, Wong Sing King \\ Department of Animal Science and Fishery, Faculty of Agriculture and Food Sciences \\ Universiti Putra Malaysia Bintulu Sarawak Campus, Nyabau Road, P.O. Box 396, 97008 Bintulu, Sarawak, Malaysia \\ E-mail: zul_shafiq87@yahoo.com.my,mhanafi@btu.upm.edu.my,hena@btu.upm.edu.my,wongsk@btu.upm.edu.my
}

\begin{abstract}
The diversity of cephalopod from nine divisions at Sarawak, Malaysia was studied from August 2010 to February 2011. Cephalopod was collected from landing stations and local wet markets of Kuching, Sri Aman, Sibu, Sarikei, Mukah, Miri, Limbang, Lawas and Bintulu. Seven species of cephalopod belongings to three families were identified during the study period. The family Loliginidae was dominated group of cephalopod which consists of three species namely Uroteuthis (Photololigo) edulis, Uroteuthis (Photololigo) chinensis and Sepioteuthis lessoniana and recorded from five divisions. The species of cuttlefishes (Family Sepiidae) were Sepia recurvirostra, Sepia aculeate and Sepiella inermis and recorded from Sarikei, Kuching and Bintulu. Octopodidae was the only one species named Cistopus indicus and found in Bintulu. The diversity of cephalopod was found highest in Bintulu with seven species while surprisingly no species of cephalopod was recorded from Limbang, Lawas and Mukah. Study suggests that the findings of this study could be useful for future reference and detail study on cephalopod in the coastal water of Sarawak, Malaysia.
\end{abstract}

Keywords - Cephalopoda; Mollusca; diversity; Sarawak.

\section{INTRODUCTION}

Cephalopod is an ancient group of Mollusca and approximately 700 species have been identified in the world. Living cephalopods include nautiluses, bottle squids and bobtail, pygmy cuttlefishes, cuttlefishes, squids, and octopuses. In South Asian countries, cephalopod species are very common in South China Sea and other adjacent sea areas including the Northern end of South China Sea [1]. However, the diversity of cephalopod is higher in Japanese sea water than South China Sea [2].

Generally, Loliginidae, Octopodidae and Sepiidae are the common family in cephalopod. The species Uroteuthis (P.) edulis and $U$. (P.) chinensis from Loliginidae family are common cephalopod found in a commercial market. Loliginidae are opportunistic carnivores and grow rapidly, and exists in temperate and tropical oceans. They are seven in genera with 50 species. Studies recorded that there are about 13 species of Loliginidae in the water area of South China Sea followed by 19 species for Sepiidae and over 40 species for Octopodidae [3].

Studies on the distribution, abundance and species composition with biological parameters of some commercially important fishery species have been carried out in Sarawak coastal area [5]. Although few studies on squid survey in coastal waters of Malaysia have been carried out [6], but, the study on the diversity of cephalopod in Sarawak coastal area is less. Hence this study is inaugurated. The aims of this present study are to investigate and identify the diversity of cephalopod at the selected division of Sarawak. It is expected that the findings of this study could be useful for future reference and detail study on cephalopod in the coastal water of Malaysia.

\section{MATERIALS AND METHODS}

Cephalopod samples were collected from different wet markets and fish landing centres in nine divisions namely Kuching, Sri Aman, Sarikei, Mukah, Sibu, Bintulu, Miri, Limbang and Lawas from August 2010 to February 2011 (Fig 1). Nine visits were made to each landing centers in the mornings between 6 a.m. and 10 a.m. All samples were placed in the ice box and brought back to the laboratory for future analysis. Samples were cleaned with tap water and unwanted materials were removed from the body of Cephalopod. Identification of Cephalopod was done following the materials published by FAO [4]. 


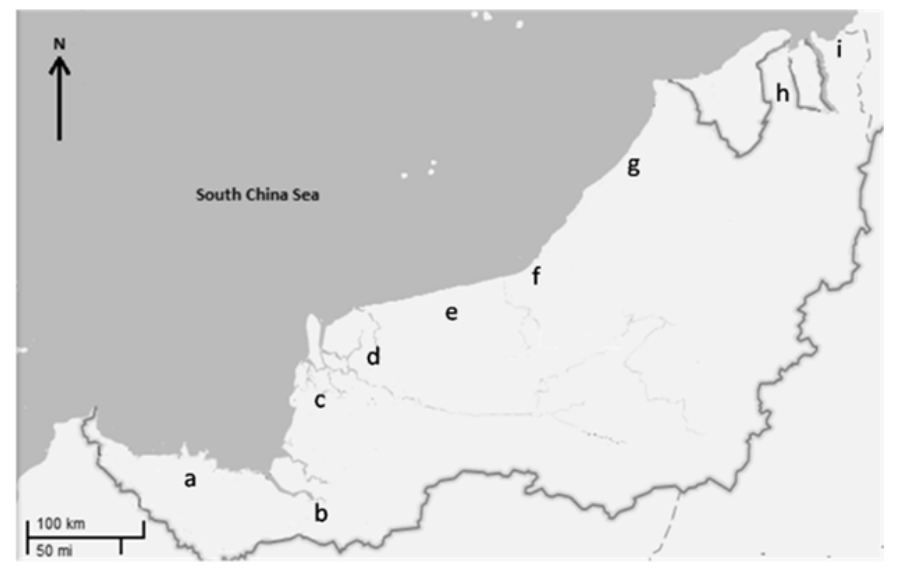

Fig 1 Map showing the collection sites (a-i) of Sarawak, Malaysia. (a) Kuching, (b) Sri Aman, (c) Sarikei, (d) Sibu, (e) Mukah, (f) Bintulu, (g) Miri, (h) Limbang and (i) Lawas

\section{RESULTS AND DISCUSSION}

Seven species of cephalopod i.e., Uroteuthis (Photololigo) chinensis, Uroteuthis (Photololigo) edulis, Sepioteuthis lessoniana, Cistopus indicus, Sepia aculeate, Sepia recurvirostra and Sepiella inermis belonging to three families (Loliginidae, Octopodidae and Sepiidae) were identified during the investigation period from nine divisions of Sarawak (Fig 2). Surprisingly, no species of cephalopod was recorded from the coastal area of

Limbang, Lawas and Mukah which is needed future investigation.

The most common species was Uroteuthis (P.) edulis in the cephalopod group in the coastal area of Sarawak. The species Sepioteuthis Lessoniana, Uroteuthis (P.) chinensis and Sepia aculeate were found as irregular distribution pattern during the sampling period and recorded from four to one division only (Table 1). The Loliginidae and Sepiidae types of cephalopod were found higher in number (43\%) compared to Octopodidae (14\%) in the coastal area of Sarawak (Fig. 3). On the other hand, the diversity of cephalopod is higher in Bintulu division compared to other divisions studied in this present study (Fig. 4).

Cephalopods are one of the most important marine fishery resources all over the world. However, it is not well studied in the Sarawak coastal water. Seven species of cephalopods were observed from the nine coastal division of Sarawak out of seventy two (72) species available in the South China Sea [3]. Compared to the recorded value by Norman and $\mathrm{Lu}$ [3] and FAO [4] the present recorded features of cephalopods were lower probably due to the water circulation patterns, nutrient status, habitat or geographical differences.

Studies reported that cephalopod is a very important commercial fishery industry in China [8, 9], Taiwan [10] and Thailand [11]. The species Uroteuthis (P.) chinensis accounts for up to $90 \%$ of the Loliginidae catch in several parts of China and $15-40 \%$ of the trawl catch in the Gulf of Thailand [11]. Uroteuthis (P.) chinensis was abundant and dominant species in the bottom trawls in the South China Sea [12, 13] when compared with this study. It is thought that the cephalopods recorded during this present study could be native in this area even though their presence and availability in certain divisions were irregular. This incident could probably be due to the variable of natural recruitment, breeding season [May to March; August to September (12)], water salinity, depth and temperature [14]. However, the distribution, composition and abundance of cephalopods are also depends on the geographical locations and habitat differences.

TABLE I

SPECIES CHECKLIST OF CEPHALOPODA AT EIGHT DIVISION OF SARAWAK

\begin{tabular}{lll}
\hline Family & Species & Division \\
\hline Loliginidae & Uroteuthis (Photololigo) chinensis & a, e, f \\
& & a, b, c, \\
& Uroteuthis (Photololigo) edulis & d, e, f \\
& Sepioteuthis lessoniana & a, c, e, f \\
Octopodidae & Cistopus indicus & e \\
Sepiidae & Sepia aculeata & b, c, e \\
& Sepia recurvirostra & e \\
& Sepiella inermis & e \\
\hline Note; a: Kuching, b: Sarikei, c: Sibu, d: Sri Aman, e: Bintulu, f: Miri
\end{tabular}

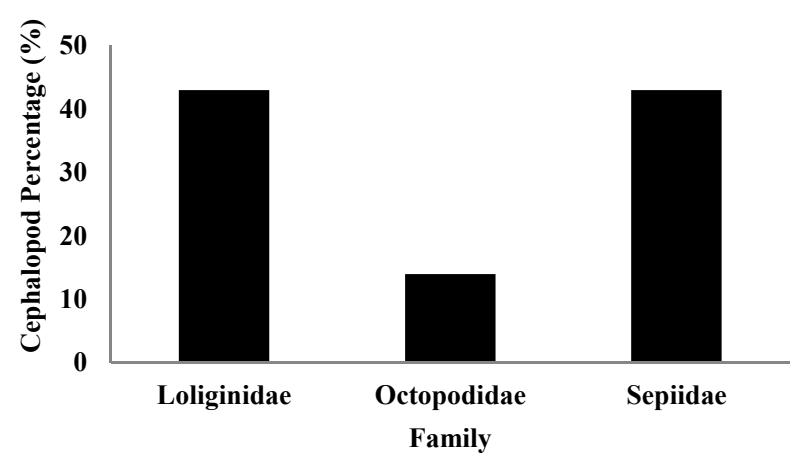

Fig. 2. Percentage of cephalopod family at the nine selected divisions of Sarawak.

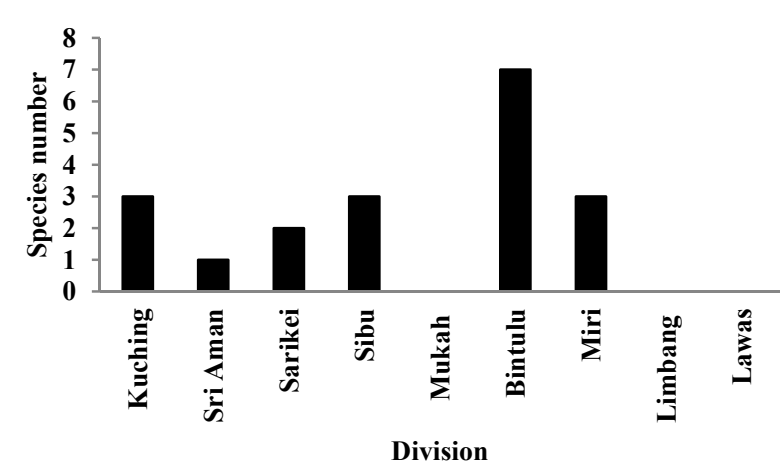

Fig 3. Species number for each of selected division at Sarawak

\section{CONCLUSIONS}

Cephalopod is a common and important fisheries species in Malaysia in terms of domestic consumption and economic value. Therefore, to launch this fisheries industry in the country, it is needed to understand the factors those controlling annual recruitment, biology, reproduction and habitat of cephalopods in Malaysian water area. 


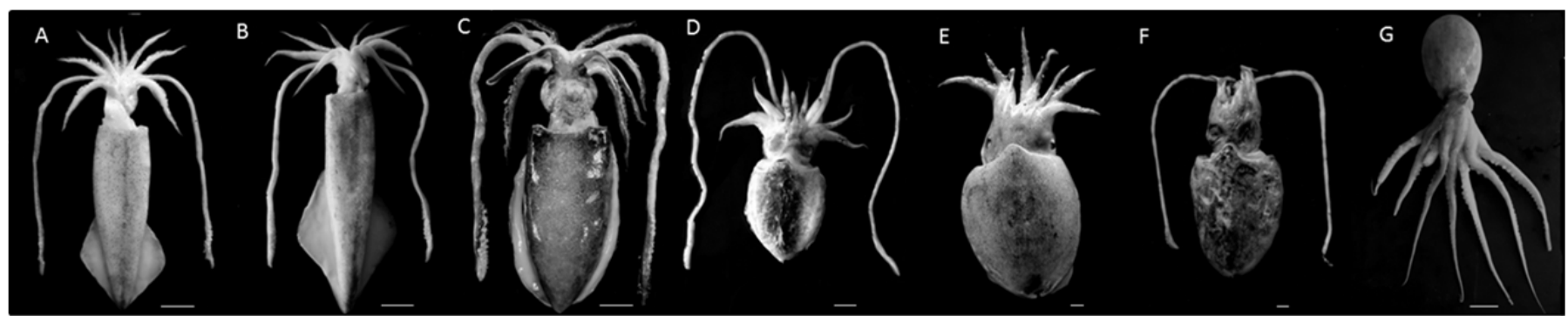

Fig 4. Species of cephalopod (A) U. (P.) edulis, (B) U. (P.) chinensis, (C) S. lessoniana, (D) S. recurvirostra, (E) S. inermis, (F) S. aculeata, and (G) C. indicus (scale bar $5 \mathrm{~cm})$

\section{ACKNOWLEDGMENT}

Author would like to thanks Universiti Putra Malaysia for financial support of this research (Project No: 5523703 FRGS) which make this study possible.

\section{REFERENCES}

[1] T. Okutani, M. Tagawa and H. Horokawa, Cephalopods of continental shelf and slope around Japan, Japan Fisheries Resource Conservation Association, Tokyo, p. 194, 1987.

[2] M. Sasaki, A monograph of the dibranchiate cephalopods of the Japanese and adjacent waters, Journal College Agriculture Hokkaido Imperial University, vol 20, pp. 1-357, 1929.

[3] M. D. Norman and C. C. Lu, Preliminary checklist of the cephalopods of the South China Sea, The Raffles Bulletin of Zoology, vol 8, pp. 539-567, 2000.

[4] FAO, Food and Agriculture Organization Fishery Statistics. Rome Italy, 1998.

[5] R. Richard, A. Awang, M. Jamil and B.Rooney, Distribution, abundance and biological studies of economically important fishes in the South China Sea, area II: Sarawak, Sabah and Brunei Darussalam waters, p. 353-361, 1996.
[6] S. A. Zainal and R. I. Abdul, Preliminary squid survey in coastal waters off Kuala Terangganu, Malaysia, Asian Fisheries Science, vol 5, pp. 261-264, 1992.

[7] Anon, Annual Fisheries Statistics. Marine Fisheries Department of Sarawak. Ministry of Agriculture Malaysia, 1995.

[8] J. E. Gray, Catalogue of the Mollusca in the Collection of the British Museum, I: Cephalopoda Antepedia. British Museum (Natural History), London, 1849.

[9] W. E. Hoyle, Diagnoses of new species of Cephalopoda collected during the cruise of H. M. S. Challenger, 11: The Decapoda. Annals and Magazine of Natural History, series 5, vol 16, pp. 181-203, 1885.

[10] G. L. Voss and G. R. Williamson, Cephalopods of Hong Kong. Hong Kong Government Press, Hong Kong, p. 138, 1971.

[11] C. F. E. Roper, M. J. Sweeney and C.E., Nauen, FAO species catalogue. Vol. 3. Cephalopods of the world. An annotated and illustrated catalogue of species of interest to fisheries. FAO Fisheries Synopsis, vol 125, p. 277, 1984.

[12] S. Chikuni, Cephalopod resources in the Indo-Pacific region, In Journal Fiheries Caddy, pp. 264-305, Ed. Advances in accessment of world Cephalopod resources, FAO Tech, p. 231, 1984.

[13] E. H. Chan and M. N. Karim, Preliminary data on squid (Loliginidae) from the Matahari Expedition 1985, Occasional Publication No. 3 Faculty of Fisheries and Marine Science, Universiti Putra Malaysia, Selangor, 1987.

[14] FAO, Squid Recruitment Dynamics, FAO fisheries Technical Paper, p. $376,1998$. 